\title{
TACTICS USED BY THE TERRORIST ORGANISATION BOKO HARAM
}

\author{
Marius PRICOPI \\ pricopi.marius@armyacademy.ro \\ “NICOLAE BĂLCESCU” LAND FORCES ACADEMY, SIBIU, ROMANIA
}

\begin{abstract}
Boko Haram is no regular terrorist organization; although not as widely-known as the Islamic State or Al-Qaeda, Boko Haram has been declared the deadliest terror group of 2014. Fortunately, the organization seems to currently be on the run; and the successes of the Nigerian government in countering it have been founded on a timely understanding of its modus operandi.

This paper represents an inventory and an analysis of the main tactics employed by Boko Haram in Nigeria and Cameroon during the spike of its insurgence, between the years 2009-2014. Acknowledging these tactics in a timely manner did not only contribute in a significant manner to the present defeat of Boko Haram, as it may also be of use to governments from other countries in anticipating and efficiently thwarting future terrorist plots.
\end{abstract}

\section{KEYWORDS:}

Tactics, terrorism, Boko Haram

\section{Introduction}

For some, it may come as a surprise that, in 2014, Boko Haram was the deadliest terrorist organization in the world. After all, Boko Haram has not received wide media coverage as did Al-Qaeda or the Islamic State, nor has it been linked in any consistent manner by analysts and political deciders with the on-going refugee crisis; the actions of Boko Haram have not generated worldwide empathy for their victims, nor have they managed to unite the world's most powerful organizations and states in providing a decisive answer.

Still, the facts remain. According to the latest data (Institute for Economics and Peace, 2015), out of the 20 most fatal terrorist attacks committed in 2014, 9 have been claimed by or attributed to Boko Haram, with an average of 14 deaths/ terrorist attack. The same year, the terrorist activity of Boko Haram generated no less 
than 6,644 deaths, the total number of related Boko Haram kills since the start of the insurgency in 2009 reaching the stunning number of 20,000 .

If we were to provide a clearer picture of what Boko Haram means to its host country, let us just point out that in 2014 the organization generated over $80 \%$ of deaths from terrorism in Nigeria, which thus witnessed the largest increase in such killings recorded by any other country (over $300 \%$ ). Nigeria thereby came to hold the second highest number of terrorism-related deaths in the world, being exceeded only by Iraq - a country torn by war, insurgencies and sectarian violence.

Knowing in due time how the terrorist tactics of Boko Haram evolved was extremely important, as this knowledge represented a major factor for success in their defeat by the governmental forces.

\section{Methodology}

The current paper is a study of the tactics employed by the terrorist organization Boko Haram first in the country of Nigeria and then - as insecurity tends to overspill (Neag, Raţiu \& Ispas, 2010; Grigoraş, 2015) - in Cameroon. As a research method we used the analysis and synthesis of social documents, based on the benchmarks depicted by Septimiu Chelcea in his 2004 reference book. The method allowed a necessary diversification of information and welcomed critical points of view based on the value and the limits of the consulted literature.

As the most recent complete data regarding the terrorist activity of Boko Haram have been compiled for the year 2014, the principal time frame for this article starts with 2009 (the beginning of the insurgency) and ends with 2014.

\section{Results and Discussions}

Between 2009-2014, most of the attacks carried out by Boko Haram were armed assaults (Institute for Economics and Peace, 2012, 2014 and 2015), in which firearms - especially machine guns - were the main types of weapons used (Table no. 1); according to data provided by the Global Terrorism Index (Institute for Economics and Peace, 2015), these types of attacks resulted in $63 \%$ of deaths in 2014. Let us consider, as an example, the Nigerian town of Baga where, between January 3 and January 7, 2015 Boko Haram conducted a series of mass killings resulting in over 2,000 deaths.

Table no. 1

Types of weapons used by members of Boko Haram in their 10 worst terrorist attacks between 2009-2014

\begin{tabular}{|c|c|c|c|c|}
\hline Rank & Date/Period & City/District & Fatalities & Weapon Type \\
\hline 1. & $03-07.01 .2015$ & Baga & 2,000 & Firearms \\
\hline 2. & 05.05 .2014 & Gamboru Ngala & 315 & Explosives/Bombs/Dynamite \\
\hline 3. & 27.07 .2009 & Maiduguri & 304 & Unknown \\
\hline 4. & 14.03 .2014 & Maiduguri & 212 & Explosives/Bombs/Dynamite \\
\hline 5. & 17.09 .2014 & Konduga & 201 & Explosives/Bombs/Dynamite \\
\hline 6. & 13.05 .2014 & Kalabalge & 200 & Firearms \\
\hline 7. & 18.09 .2013 & Beni Shiek & 161 & Firearms \\
\hline 8. & 13.05 .2014 & Garawa & 151 & Firearms \\
\hline 9. & 17.09 .2013 & Beni Shiek & 142 & Firearms \\
\hline 10. & 24.10 .2013 & Damatura & 125 & Explosives/Bombs/Dynamite \\
\hline
\end{tabular}


But as they were starting to be put on the run by the Nigerian security forces, the terrorist switched tactics. As a follow-up to the special military training that the terrorists received from other similar groups, in 2014 tactics such as bombing increased 3 times, from 35 incidents in 2013 to 107 incidents in 2014. Yet, the increase of deaths from bombings was far more consistent: in 2014 approximately 1,490 people died in bombings, 14 times more than the 107 people who died in the same manner in 2013. And, as predictable, many bombings targeted civilians in public places: $38 \%$ of the ones killed by Boko
Haram in 2013 were private citizens, whereas in 2014 the percentage arose to $77 \%$.

Consequently, the year 2014 also brought a spike in suicide attacks conducted by Boko Haram. Although until then these types of tactics were rather rare, in 2014 Boko Harem accounted for 31 suicide attacks (Institute for Economics and Peace, 2015), the majority of them targeting, again, civilians or education and religious institutions.

Actually, for the entire 2012-2014 period, a clearer picture of the targets and types of weapons used by Boko Haram is provided, based on data made available by the Global Terrorism Database (2015), in Figure no. 1 and Figure no. 2.

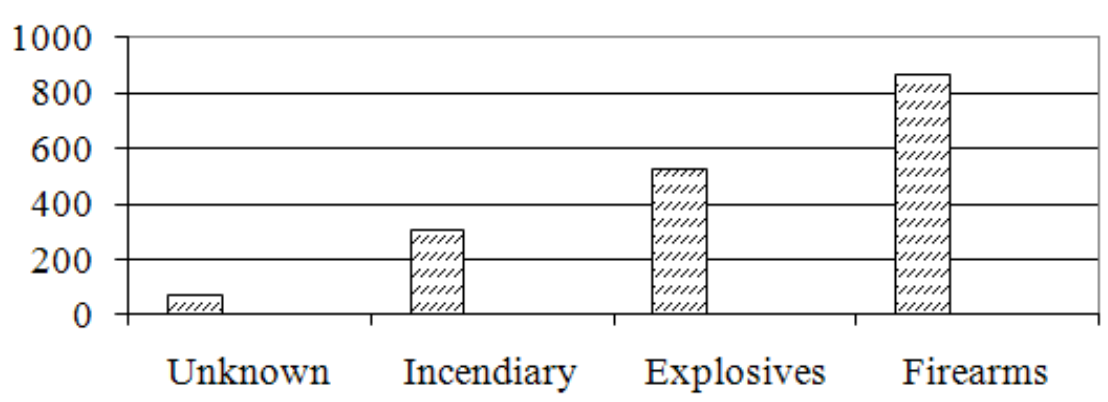

Figure no. 1 Targets of Boko Haram in various attacks committed between 2012-2014

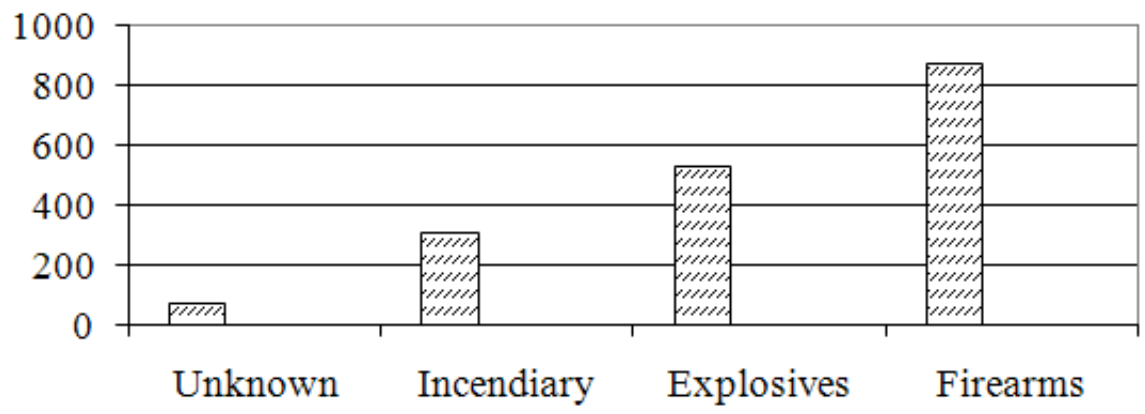

Figure no. 2 Types of weapons used by Boko Haram in various attacks committed between 2012-2014

A different tactic of Boko Haram, which had actually become a trademark of this group, was the use of women in terrorist actions. Within the organization, women had either simple support roles, or they were actively involved in unlawful and violent deeds, such as arms smuggling, armed assaults or suicide bombings.
Using women in terrorist activities is not a new tactic, and the reasons behind it are rather simple: women are less suspicious than men, they are often searched in a looser manner and their clothes permit them to easily conceal weapons or bombs.

But lacking the successful propaganda and appeal of organizations like the Islamic 
State, the majority of women involved by Boko Haram in terrorist attacks were forced to do so. As one editorialist wrote in The New York Times (Searcey, 2016), "of all the many horrors of Boko Haram's rampage across West Africa - the attacks on mosques, churches and schools; the mass killings of civilians; the entire villages left in ashes after militants tear through one of the most baffling has been its ability to turn captured women and girls into killers".

Using women and girls in terrorist actions was definitely a planned and thought-out tactic that started with the kidnapping of some 300 girls in April 2014, from a school in Nigeria. Since then, hundreds of women and girls were abducted, forcefully trained and used in terrorist attacks. The results were almost immediate.

Since the 2014 kidnapping, Boko Haram used at least 100 women and girls in suicide attacks carried out in public places such as markets, schools, river docks or even refugee camps for internally displaced people. Also, out of the 34 suicide bombings perpetrated in the neighbouring Cameroon, $80 \%$ involved girls and women aged 14 to 24 years (Al Jazeera, 2016). Note, for example, the February 2016 attack in a Nigerian camp, where two female bombers (aged 17 and 20) blew themselves up, killing approximately 60 people and injuring around 80. According to $\mathrm{CNN}$ (Abubakar, Melvin \& Busari, 2016), a third female bomber refused to carry out the attack, after realizing that her family was accommodated in the camp.

But as security forces became more and more aware of the threat posed by female suicide bombers, the terrorists again changed their tactics: they started to literally disguise themselves as mad people, in order to gain unsuspicious access to public places and detonate themselves. Moreover, in January 2016, two male suicide bombers even disguised themselves in mad women, to obtain access in a public market, thus killing approximately 10 people and injuring many more. The Nigerian governmental forces shortly noticed this behaviour and, in response, casted security alerts to citizens, advising them "to be wary of mad persons approaching markets, public places or crowded areas" (Premium Times, 2016).

Another terrorist tactic of Boko Haram consisted of raids on towns and villages in the North-Eastern part of Nigeria. According to an Amnesty International report (2015), "some attacks were carried out by just two or three gunmen on a motorcycle, some by hundreds of fighters supported by tanks and antiaircraft weapons mounted on flat-bed trucks". In a series of these raids, terrorists conducted indiscriminate killings, robberies and abductions, while in others they simply assassinated individuals identified ahead of time. In most of the raids, serious damage has been inflicted on the critical infrastructures of the communities; as argued (Badea, Oancea, Coman \& Ionescu, 2015), the damages generated an even heavier strain on the overall state of security of those affected communities. Moreover, some villages, like Kayamla, were raided on multiple occasions, thus ensuing large fluxes of internally displaced persons.

Finally, a more elaborate tactic favoured by Boko Haram consisted of taking control of towns and villages. When this was the case, hostilities usually respected the following sequence of events (Amnesty International, 2015): first, large numbers of terrorists assaulted the communities, initially targeting police or military institutions and facilities; after government forces were neutralized or determined to abandon their posts, the terrorists captured the arms and ammunition left behind; then they targeted civilians, either gunning them down as they tried to escape or executing them in their own homes; simultaneously, terrorist looted shops, collected private valuables, set houses on fire and abducted residents.

\section{Conclusions}

Currently, the intensity of the terrorist activity of Boko Haram has been 
diminished, mainly thanks to the concerted actions taken by the Nigerian government. It remains difficult to foresee whether the organization will be capable of bouncing back, but for now at least on aspect is clear: the submission of the terrorists started with the comprehension of the tactics they used.

And it seems they used them all: armed assaults and bombing, suicide attacks, exploit of women in terrorist actions, disguising as mad people to gain unrestricted access in public places, raids on towns and villages or even taking control of entire communities.

Acknowledging in due time the tactics of Boko Haram allowed the authorities to score significant successes, by: planning and conducting efficient counterterrorism actions; warning in reasonable time the local population on the modus operandi of the terrorists; anticipating and even preventing further terrorist actions, thus saving an inestimable number of lives.

Moreover, we consider that knowing the tactics employed by Boko Haram could be of use in countering other terrorist organizations. Having a complete inventory of these tactics, authorities from other countries or regions may anticipate and efficiently thwart future terrorist plots. After all, as is widely accepted, to defeat an enemy one must first know how it acts.

\section{Acknowledgement}

This paper has been elaborated during the sustainability period of the project entitled „Horizon 2020 - Doctoral and Postdoctoral Studies: Promoting the National Interest through Excellence, Competitiveness and Responsibility in the Field of Romanian Fundamental and Applied Scientific Research", contract number POSDRU/159/1.5/S/140106. This project was cofinanced by European Social Fund through Sectoral Operational Programme for Human Resources Development 2007-2013. Investing in people!

\section{REFERENCES}

Abubakar A., Melvin D. \& Busari, S. (2016). Female suicide bombers kill 58 in a Nigerian camp meant to be a haven. CNN, February 11, 2016, Retrieved from: http://edition.cnn.com/2016/02/11/africa/nigeria-suicide-bombing-boko-haram/, accessed on May 31, 2016.

Al Jazeera. (2016). Boko Haram attacks Cameroon with kidnapped girls. Al Jazeera, April 1, 2016. Retrieved from: http://www.aljazeera.com/news/ 2016/03/weakened-bokoharam-sends-girl-bombers-cameroon-1603311758 22717.html, accessed on May 31, 2016.

Amnesty International (2015). Our Job is to Shoot, Slaughter and Kill: Boko Haram's Reign of Terror in North-East Nigeria. London: Amnesty International Ltd.

Badea, D., Oancea, R., Coman, M. \& Ionescu, C. (2015). Opportunity and Utility in Applying Scenarios Method in the Critical Infrastructures Protection Field. Buletin Ştiinţific, vol. $X X$, no. 2 (40), pp. 125-131.

Chelcea, S. (2004). Iniţiere în cercetarea sociologică. Bucureşti: Comunicare.ro, pp. 235-262.

Global Terrorism Database. (2015). Boko Haram. Retrieved from: https://www.start.umd.edu/gtd/search/Results.aspx? charttype=bar\&chart=target\&search=bok o\%20haram, accessed on May 30, 2016.

Grigoraş, R. (2015). Corelaţii ale războiului şi factorii de influenţă ai securităţii statelor. Buletinul Universităţii Naţionale de Apărare „Carol I”, vol. 2, no. 1, pp. 132-138.

Institute for Economics and Peace. (2012). Global Terrorism Index. Retrieved from: http://reliefweb.int/sites/reliefweb.int/files/resources/2012-Global-Terrorism-Index-Report.pdf, accessed on May 28, 2016. 
Institute for Economics and Peace. (2014). Global Terrorism Index. Retrieved from: http://www.visionofhumanity.org/sites/default/files/Global\%20Terrorism\%20Index\%20

Report\%202014_0.pdf, accessed on May 28, 2016.

Institute for Economics and Peace. (2015). Global Terrorism Index. Retrieved from: http://economicsandpeace.org/wp-content/uploads/2015/11/Global-Terrorism-Index-2015.pdf, accessed on May 26, 2016.

Neag, M., Raţiu, A., \& Ispas, L. (2010). Approaching military transformation through modern doctrinaire - operational concepts. International Journal of Academic Research, vol. 2, no. 5, pp. 312-314.

Premium Times. (2016). Nigerian military reveals Boko Haram's new tactics to bomb Nigerians. Premium Times, January 30. Retrieved from: http://www.premiumtimesng.com/ news/headlines/197681-nigerian-military-reveals-boko-harams-new-tactics-bombnigerians.html, accessed on June 1, 2016.

Searcey, D. (2016). Boko Haram Turns Female Captives Into Terrorists. The New York Times, April 7. Retrieved from: http://www.nytimes.com/2016/04/08/world/africa/ bokoharam-suicide-bombers.html, accessed on May 31, 2016. 